\title{
Dues Disputes Under the Railway Labor Act
}

In 1951, Congress amended the Railway Labor Act to allow unions and carriers to enter into union shop agreements. ${ }^{1}$ Under the union shop proviso, Section 2 Eleventh, the union can have an employee fired for failing to maintain his membership. Employee rights, however, are protected by the requirements that (a) union membership be offered on substantially equal terms to all employees and (b) the only material requirement of membership be the periodic payment of dues, fees, and assessments. Only if provisions guaranteeing these rights are a part of the collective bargaining agreement, can an employee be dismissed for defaulting on his union obligations. ${ }^{2}$

Despite these precautions, this power of the union to have an employee discharged lends itself to abuse. Dues clauses can perform the

[1.] The relevant portion of the section states:

Eleventh. Notwithstanding any other provisions of this Act ... any carricr or car. riers as defined in this Act and a labor organization or labor organizations duly designated and authorized to represent employees in accordance with the requircments of this Act shall be permitted-(a) to make agreements, requiring, as a condition of continued employment, that within sixty days following the beginning of such employment, or the effective date of such agreements, whichever is the later, all employees shall become members of the labor organization representing their craft or class: Provided, That no such agreement shall require such condition of employment with respect to employees to whom membership is not available upon the same terms and conditions as are generally applicable to any other member or with respect to employees to whom membership was denied or terminated for any reason other than the failure of the employee to tender the periodic dues, initiation fees, and assessments (not including fines and penalties) uniformly required as a condition of acquiring or retaining membership.

(d) Any provisions in paragraphs Fourth and Fifth of section 2 of this Act in conflict herewith are to the extent of such confict amended.

Railway Labor Act \& 2 Eleventh, as amended, 64 Stat. 1238 (1951), 45 U.S.C. \$ 152 Eleventh (1964).

[2.] The Senate Report makes this quite explicit:

The bill attaches two conditions to the execution of union-shop agreements:

First, the agreement may not require membership in the labor organization as a condition of employment with respect to employees to whom membership is not available on the same terms and conditions as are generally applicable to any other members. Under this provision a labor organization cannot require union membership as a condition of employment if it refuses to accept the membership of per. sons of certain classes or offers them only limited membership.

The second condition set up is that the agreement may not require membership in the labor organization as a condition of employment with respect to employees to whom membership was dened or terminated for any reason other than the failure of the employee to tender the periodic dues, initiation fees, and assessments uni. formly required as a condition of acquiring or retaining membership. The effect of this condition is to remove from the requirements of any union shop agrecmenl those employees to whom membership has been denied or who have been expelled from membership for any cause except nonpayment of dues, fees, and assessments. In such cases, non-membership in the labor organization could not be used as the basis for the dismissal of the employee by the carrier.

S. REP. No. 2262, 81 st Cong., 2d Sess. 2 (1950). (Emphasis added.) 
office of the Mississippi literacy test, particularly if they are complicated and legalistic. They may enable the union leaders to harass dissident members and to eliminate their adversaries. Thus, in reported cases, non-payment of dues is normally not the real reason why the employee has been cited to the employer for discharge. ${ }^{3}$ But the union will claim non-payment, since that ground alone justifies dismissal under Section 2 Eleventh.

Under present law, a union may easily succeed in this deception. An ex-employee who claims he has paid his dues may find no impartial forum to hear his case. Federal courts of appeals have held that the judiciary lacks jurisdiction over such disputes, reasoning that the union security clause is part of the collective bargaining agreement, ${ }^{4}$ and that, under the RLA, the employee's sole remedy for contract grievances is before the bilateral Railroad Adjustment Board. ${ }^{5}$ Only where the employee has invoked the judicially created doctrine of "hostile discrimination," by alleging that the union has not fairly represented him in its dealings with the employer, have the courts been willing to consider the complaint. $^{6}$

A new, more receptive doctrine was recently announced by the District Court for Delaware. In Brady v. Trans World Airlines, Inc. ${ }^{7}$ the court held that dues cases arise under the statutory ban on employer coercion, Section 2 Fourth of the RLA, ${ }^{8}$ and not simply under the

[3.] E.g., Cunningham v. Erie R.R., 266 F.2d 411 (2d Cir. 1959).

[4.] Battle v. Brotherhood of Ry. \& S.S. Clerks, 320 F.2d 742 (D.C. Cir. 1953).

[5.] Slocum v. Delaware, Lackawanna \& Western R.R., 339 U.S 239 (1950); sec note 16 infra.

[6.] Cunningham v. Erie R.R., supra note 3; cf. Conley v. Gibson, 355 U.S. 41 (1957); Steele v. Louisville \& Nashville R.R., 323 U.S. 192 (1944).

[7.] 223 F. Supp. 361 (D. Del. 1963). This case has had a long history in the Delaware District Court 156 F. Supp. 82 (D. Del. 1957); 167 F. Supp. 469 (D. Del. 1958); 174 F. Supp. 360 (D. Del. 1959); 196 F. Supp. 504 (D. Del. 1961); 244 F. Supp. 820 (D. Del. 1965). [8.] The full text of $\S 2$ Fourth states:

Fourth. Employees shall have the right to organize and bargain collectively through representatives of their own choosing. The majority of any craft or class of cmployees shall have the right to determine who shall be the representative of the craft or class for the purposes of this chapter. No carrier, its officers, or agents shall deny or in any way question the right of its cmployees to join, organize, or aesist in organizing the labor organization of their choice, and it shall be unlawiul for any carrier to interfere in any way with the organization of its emplojecs, or to use the funds of the carrier in maintaining or assisting or contributing to any labor organization, labor representative, or other agency of collective bargaining, or in performing any work therefore, or to influence or coerce employees in an effort to induce them to join or remain or not to join or remain members of any labor organization, or to deduct from the wages of employees any dues, fees, assessments, or other contributions payable to labor organizations, or to collect or to assist in the collection of any such dues, fees, assessments, or other contributions: Provided, That nothing in this chapter shall be construed to prohibit a carrier from permitting an employee, individually, or local representatives of employees from conferring with management during working hours without loss of time, or to prohibit a cr- 
collective bargaining agreement. Section 2 Eleventh, the court concluded, is merely a proviso which excepted from the prohibitions of Section 2 Fourth one type of employer coercion-that entailed by the union shop. If the coercion actually practiced by the employer is not protected by Section 2 Eleventh, it must be tested by the provisions of Section 2 Fourth, over which the courts have always had jurisdiction. ${ }^{\circ}$ Consequently the employee who claims that discharge followed revocation of union membership for reasons other than dues delinquency has a Section 2 Fourth case against the employer.

The practical difference between the two approaches is substantial. Under Brady, a discharged union member has to show only that he paid his dues on time. But a much stronger case is required to establish "hostile discrimination." While that phrase has never been clearly defined, it connotes an element of malice and vendetta that may be easier for the employee to sense than to prove. Moreover, to show "hostile discrimination" the plaintiff must overcome a strong "presump. tion of regularity" in union conduct, which effectively settles good-faith disputes in the union's favor. ${ }^{10}$

These two approaches can best be evaluated by examining the framework for the protection of employee rights under the RLA. The Act, passed in 1926 and amended to nearly its present form in 1934, guaranteed the open shop ${ }^{11}$ as well as the rights of employees to organize

rier from furnishing free transportation to its employees while engaged in the business of a labor organization.

Railway Labor Act \& 2 Fourth, as amended, 48 Stat. 1187 (1934), 45 U.S.C. § 152 (1964). (Relevant portion for Brady decision italicized.)

[9.] Railway Employees Co-op. Ass'n v. Atlanta B. \& C.R.R., 22 F. Supp. 510 (D. Ga, 1938). See also Texas \& N.O.R.R. v. Brotherhood of Ry. \& S.S. Clerks, 281 U.S. 548 (1930), where the Court found jurisdiction in the federal courts to enforce the original Section 2 Third of the Act, 44 Stat. 578 (1926). The Court stated:

It is thus apparent that Congress, in the legislation of 1926, while elaborating a plan for amicable adjustments and voluntary arbitration of disputes betwcen com. mon carriers and their employees, thought it necessary to impose, and did impose, certain definite obligations enforceable by judicial proceedings.

Id. at 567. Significantly, the present Section 2 Fourth, 48 Stat. 1186 (1934), was simply an elaboration of the original Section 2 Third, 44 Stat. $578(1926)$, and it is obvious that Congress, acting in the light of Texas \& N.O.R.R. v. Brotherhood of Ry. \& S.S. Clerks, supra, intended for its enforcement to be identical.

[10.] See Wellington, Union Democracy and Fair Representation: Responsibility in a Federal System, 67 YALE L.J. 1327, 1339-43 (1958); Kroner, Minor Disputes Under the Railway Labor Act: A Critical Appraisal, 37 N.Y.U.L. REv. 41, 62.63 (1962). The court in Cunningham v. Erie R.R., supra note 3, at 417, stated:

[1]n order to establish a breach by the union of its duty to represent the employecs fairly, as the bargaining representative of the employees sanctioned by statute, it is not enough to prove that the union was wrong in demanding Cunningham's dis. missal. This duty was no more than to forbear from "hostile discrimination." The arbitrariness shown must be of the bad faith kind. . . . Something akin to factual malice is necessary.

[11.] The relevant part of the section states:

Fifth. No carrier, its officers, or agents shall require any person sceking employment 
unions and to bargain collectively. ${ }^{12}$ Section 2 Fourth prohibited the employer from both pro and anti-union coercion. ${ }^{13}$ The 1934 amendment to the Act established the National Railroad Adjustment Board to arbitrate employee grievances arising from the collective bargaining agreement. ${ }^{14}$ The NRAB was composed of an equal number of representatives of the employer and the union, ${ }^{15}$ and by 1950 had acquired exclusive jurisdiction over contract grievances. ${ }^{10}$ An employee with a complaint simply contacted his bargaining representative, who tried to

to sign any contract or agreement promising to join or not to join a labor organization; and if any such contract has been enforced prior to the effective date of this chapter, then such carrier shall notify the employees by an appropriate order that such contract has been discarded and is no longer binding on them in any way. Railway Labor Act $\S 2$ Fifth, as amended, 48 Stat. 1188 (1934), 45 U.S.C. $\S 152$ Fifth (1964).

[12.] The relevant sections of the statute are:

Third. Representatives, for the purposes of this chapter, shall be designated by the respective parties without interference, influence, or cocrcion by cither party over the designation of representatives by the other; and neither party shall in any may interfere with, influence, or coerce the other in its choice of representatives. Representatives of employees for the purposes of this chapter need not be persons in the employ of the carrier, and no carrier shall, by interference, infuence, or coercion seek in any manner to prevent the designation by its emplojees as their representatives of those who or which are not employees of the carrier.

Railway Labor Act \& 2 Third, as amended, 48 Stat. 1187 (1934), 45 U.S.C. \$ 152 Third (1964).

[13.] See note 8 supra.

[14.] Railway Labor Act \& 3, as amended, 48 Stat. 1189 (1934), 45 U.S.C. \& 153 (1964). The Act as passed in 1926 also provided for adjustment boards but they were to be established by the parties. 44 Stat. 578 (1926). These proved unsuccessful and led to the 1934 amendment, 48 Stat. 1189.

[15.] The National Railroad Adjustment Board is composed of 36 members, 18 of which are chosen by the carriers, the other 18 by the unions. The statute allows the NRAB to delegate its power to regional or supplemental boards whenever they feel it is justified, but there has been little experience with such boards as jet. The statute also allows the parties to set up their own system board-an altemative used to a signilicant extent only by the airlines. Like the NRAB, both the regional and system boards are composed of equal numbers of representatives of the carriers and unions. Railway Iabor Act \& 3 First (w), as amended, 48 Stat. 1193 (1934), 45 U.S.C. § 153 First (w) (1964); Railway Labor Act \& 3 Second, as amended, 48 Stat. 1193 (1934), 45 U.S.C. $\$ 153$ Sccond (1964). See Kroner, supra note 10, at 71-75.

[16.] For the purpose of brevity, no mention has been made of the concurrent jurisdiction controversy which occurred before the passage of Section 2 Eleventh. After the establishment of the Adjustment Board in 1934, the state courts generally maintained that they had jurisdiction concurrent with the Adjustment Board over emplojec grievances and disputes arising from interpretation or application of the collective bargaining agreement. Via diversity jurisdiction some federal courts also heard such cases and their position was given strong support by the Supreme Court in Mroore v. Illinois Central R.R., 312 U.S. 630 (1911). However, the Court retreated from this position and in a series of cases, Order of Ry. Conductors v. Pitney, 326 US. 561 (1916), Slocum v. Dclawarc, L. \& W.R.R., 339 U.S. 239 (1950), and Order of Ry. Conductors v. Southern Ry., 339 U.S. 255 (1950), it vested exclusive jurisdiction in the Railroad Adjustment Board for all such disputes except those involving wrongful discharge. An action for vrongful discharge does not involve reinstatement and is an unsuitable remedy for the problem in this note. For a more detailed discussion of the concurrent jurisdiction controversy, see Comment, Railroad Labor Disputes and the National Railroad Adjustment Board, is U. CHI. L. REv. 303 (1951); Kroner, supra note 10, at 57-59; Rose, The Railuay Labor Act and the Jurisdiction of the Courts, 8 LAB. L.J. 9 (1957). 
settle the matter with the employer. Failing this, the representative was expected to prosecute the grievance before the Adjustment Board. ${ }^{17}$

The statutory scheme overlooked the possibility that the union's interest might conflict with the worker's. At first, the Board resolved such conflicts simply by denying a hearing to an employee whose grievance did not have union support.18 Though the Board subsequently agreed to let the individual prosecute his own complaint, its built-in bias has made it virtually impossible for the worker to win a dispute with his union. ${ }^{10}$ The union's representatives on the Board oppose him, while the employer's are normally indifferent.

In the 1944 case of Steele v. Louisville or Nashville R.R., ${ }^{20}$ the Su* preme Court acted to protect the rights of the employee by inventing the doctrine of "hostile discrimination" as a basis for court jurisdiction. In Steele a group of Negro employees complained that the union had negotiated a discriminatory agreement. The bargaining representative refused to do anything about the grievance and the employees sued in state court. The Supreme Court found jurisdiction on the theory that the grant of power to the union imposed a corresponding duty to represent all employees fairly and without "hostile discrimination." first the doctrine applied only to contracts which discriminated by their terms, but in 1957 it was extended to discriminatory administration of the contract.22

Thus, when Section 2 Eleventh was passed in 1951, the enforcement of individual rights had taken on the following pattern: if the employee's complaint was that he was denied his statutory right to be free of union-related employer coercion or discrimination, he could sue in court under Section 2 Fourth; while if his right arose from the collective bargaining agreement he had to go to the adjustment boards, unless he

[17.] For a more thorough discussion of Adjustment Board procedure, sec Kroncr, supra note 10, at 44-46, 71-75; Northrup \& Kahn, Railroad Grievance Machincry: $A$ Crili: cal Analysis (parts I-II), 5 IND. \& LAB. REL. REV. 365, 540 (1952).

[18.] By 1940 individuals without the support of their unions had submitted over 400 cases to the NRAB. None had been decided on the merits. U.S. Att'y Gen. Comm. on Administrative Procedure, Administrative Procedure in Government Agencies, S. Doc. No. 10, 77th Cong., 1st Sess., pt. 4, at 7 (1941); Stcele v. Louisville \& Nashville R.R., 328 U.S. 192, 205 (1944).

[19.] Elliott, The National Railroad Adjustment Board: A Study of Institutionalized Inadequacy, January 1961, at 58 (unpublished thesis in Yale Law School Library). In the Brady case, an appeal was taken to the System Board of Adjustment prior to the suit in District Court, but the discharge was upheld. Brady v. Trans World Sirlines, 223 F. Supp. 361,363 (D. Del. 1963).

[20.] 323 U.S. 192 (1944).

[21.] Id. at 202-03.

[22.] Conley v. Gibson, 355 U.S. 41 (1957). See Sovern, The National Labor Relations Act and Racial Discrimination, 62 ColuM. L. REv. 563, 576-87 (1962); Kroner, supra note 10, at 59-63. See also Cox, The Duty of Fair Representation, 2 VILL. L. REv. 151 (1957). 
alleged that the union had discriminated against him in negotiating the contract. ${ }^{23}$

Section 2 Eleventh, which permitted the union shop, was designed to eliminate the free rider-the non-union employee who enjoyed the benefits which the union obtained for him without contributing to its support. ${ }^{24}$ For the first time the union and the carrier were permitted to negotiate "union security agreements" which, by forcing the employee to join the union, effectively conditioned continued employment on the payment of union dues. Thus the ban on employer coercion, contained in Section 2 Fourth, was relaxed to allow the employer to enforce agreements pursuant to Section 2 Eleventh. When disputes arose as to whether the employee had paid sufficient dues, the courts, arvare that the union security agreement was merely a clause in the collective bargaining agreement, applied the standard judicial doctrine that, absent a claim of "hostile discrimination," the employee's only forum was the Adjustment Board. ${ }^{25}$ This analysis overlooked the fact that Section 2 Eleventh was merely a proviso to Section 2 Fourth and did not repeal it. ${ }^{26}$ Coercive activity which exceeds the limits allowed by Section 2 Eleventh is still prohibited by Section 2 Fourth, and the employee's statutory rights are enforceable in the courts. The confusion of the courts arose from the dual nature of the dues dispute: the employee has both a contract right and a statutory right not to be fired when he has paid his dues. ${ }^{27}$ Much of this confusion would have been prevented

[23.] By 1957, the protection had been extended to the administration of the agreement. See note 22 supra and accompanying text.

[24.] See discussion by Mr. Justice Brennan in International As'n of Machinists v. Street, 367 U.S. 740, 760-64 (1961).

[25.] Battle v. Brotherhood of Ry. \&: S.S. Clerks, 320 F.2d 742 (D.C. Cir. 1963). The complete lack of protection which the Board afforded employes vrongfully discharged under union shop agreements was recognized by a presidential emergency board soon after the passage of Section 2 Eleventh. Summers, Individual Rights in Collective Agreements and Arbitration, 37 N.Y.U.L. REv. 362, 402-03 (1962). Kroner states: "Compelling employees ousted under a union shop agreement to submit their claims to the NRAB is tantamount to leaving them remediless." Kroner, supra note 10, at 63.

[26.] The Senate Report makes this clear:

[\$ 2 Eleventh] is intended to relax the prohibitions contained in paragraphs fourth and fifth of section 2 of the Railway Labor Act against all forms of union security agreements. ...

S. REP. No. 2262, 81st Cong., 2d Sess. 2 (1950). Further, Section 2 Eleventh is written in proviso form, beginning "Notwithstanding any other provisions of this chapter. . ." Railway Labor Act, § 2 Eleventh, as amended, 64 Stat. 1238 (1951), 45 U.S.C. § 152 Eleventh (1964).

[27.] When the union cites an employee to the emplojer for non-payment of dues, the employee is dismissed. The dismissal is coercive since it is designed to force the employee to meet the dues demands of the union. If the cmplojec has actually paid his dues but is dismissed, he has a claim that the contract has been violated and an seek relief before the Adjustment Board. He can also sue the union for hostile discrimination. Further, since the coercive conduct of the emplojer is not protected by Section 2 
if Section 2 Eleventh had merely been added to Section 2 Fourth rather than appearing three pages later in the United States Code.

The close kinship between the RLA and the National Labor Relations Act confirms the Brady approach. The Section 2 Fourth-Section 2 Eleventh complex of the RLA was modeled on Section 8(a)(3) of the NLRA. ${ }^{28}$ That section of the NLRA guarantees the same rights as Section 2 Fourth. ${ }^{20}$ It contains a proviso, much like Section 2 Eleventh, which permits employer coercion in enforcing a statutorily limited form of union shop. ${ }^{30}$ Any other coercion constitutes an unfair labor practice, and the aggrieved employee can obtain redress from the National Labor Relations Board. ${ }^{31}$ But unlike the Adjustment Board, the NLRB is non-partisan rather than bi-partisan and was designed to adjudicate rather than arbitrate. ${ }^{32}$ Its functions in enforcing $8(a)(3)$ correspond to those performed by the courts under Section 2 Fourth,

Eleventh, it is proscribed by Section 2 Fourth, and the employee has a statutory claim for relief cognizable by the courts.

The existence of a contract remedy cannot deprive the employce of his statutory remedy. The Brady decision emphasized this point through the following example. In International Ass'n of Machinists v. Street, 367 U.S. 740 (1961), the Supreme Court held that Section 2 Eleventh did not allow the union to use dues collected under a union shop agreement to support political candidates whom the plaintiff, a union member, opposed. Clearly, if the union and employer had included a clause in the collective bargaining agreement that the dues of dissenting employees could not be used for politi. cal purposes, the plaintiff would have had a contract grievance over which the Adjust. ment Board would have jurisdiction. Yet it would be ridiculous to conclude that he thereby lost the judicially enforceable statutory right upheld by the Court in Strcet.

[28.] "It is the view of your committee that the terms of [ $\$ 2$ Eleventh] are sub. stantially the same as those of the Labor-Management Relations Act as they have been administered. ..." S. REP. No. 2262, 81st Cong., 2d Sess. 3 (1950).

[29.] \& 8. Unfair labor practices.

(a) It shall be an unfair labor practice for an employer-

(3) by discrimination in regard to hire or tenure of employment or any term or condition of employment to encourage or discourage membership in any labor organization: Provided, That nothing in this Act, or in any other statute of the United States, shall preclude an employer from making an agreement with a labor organization (not established, maintained, or assisted by any action defined in section 8 (a) of this Act as an unfair labor practice) to require as a condition of employment membership therein on or after the thirtieth day following the beginning of such employment or the effective date of such agreement, whichever is the later . . . Provided further, That no employer shall justify any discrimination against an employee for nonmembership in a labor organization (A) if he has reasonable grounds for believing that such membership was not available to the employce on the same terms and conditions generally applicable to other members, or (B) if he has reasonable grounds for believing that membership was denied or terminated for reasons other than the failure of the employee to tender the periodic dues and the initiation fees uniformly required as a condition of acquiring or retaining membership.

Labor Management Relations Act $\S 8(a)(3)$, as amended, 61 Stat. 140 (1917), 29 U.S.C. $\S 158(a)(3)(1964)$.

[30.] Ibid.

[31.] Labor Management Relations Act § 10(a), as amended, 61 Stat. 146 (1917), 29 U.S.C. \& 160(a) (1964).

[32.] See generally Labor Management Relations Act $\S 3(a)$, as amended, 61 Stat. 139 (1947), 29 U.S.G. \& 153(a) (1964). 
not those performed by the Adjustment Board in arbitrating contract grievances. ${ }^{33}$ Just as the NLRB has jurisdiction over dues disputes under the union shop proviso to the NLRA, so the courts should take jurisdiction over such disputes arising under Section 2 Fourth-Section 2 Eleventh of the RLA.

Courts which view dues disputes only as contractual grievances, ${ }^{3 *}$ and insist on arbitration, ignore a simple fact. Dues disputes, unlike other grievances, pit the worker against both union and management. An arbitration between his antagonists is scarcely designed to do the worker justice. $^{35}$ Nor could it have been the design of Congress, when it legalized only the most limited kind of union shop, to leave everything to arbitration between the very parties whose power was being limited. Such an abdication would permit the union to approximate a closed shop by converting any disagreement into a dues dispute.

It is also sometimes argued that courts should not take jurisdiction until internal union remedies have been exhausted. But if union remedies are not available until after the employee is fired, they can do him little good. The union, alone, cannot rehire the employee, and management may already have filled his position. Moreover, internal union remedies are irrelevant where the employee, though not liable to dismissal under Section 2 Eleventh, has violated union discipline on matters other than dues payment. ${ }^{36}$

In adjudicating dues disputes, courts will have to interpret the union shop agreement, and any other documents to which it refers to deter-

[33.] The NLRA sets up no agency similar to the Railroad Adjustment Board, relying on the courts and private arbitrators to settle contract disputes. Sce Note, Section $301(a)$ and the Federal Common Law of Labor Agreements, 75 YALE L.J. 877 (1960).

[34.] E.g., Battle v. Brotherhood of Ry. \& S.S. Clerks, 320 F.2d 742 (D.C. Cir. 1963).

[35.] Commentators who have recognized the unfaimess of such arbitration procecdings have suggested that some procedure be set up in the contract whereby the cmplojec can obtain arbitration in a neutral forum. Summers, Individual Rights in Collective Agreements: A Preliminary Analysis, 9 BufFalo L. REv. 239, 252-54 (1900); Summers, Individual Rights in Collective Agreements and Arbitration, 37 N.Y.U.L. REv. 362, 102.03 (1962); Kroner, supra note 10, at 63 . A number of carriers and unions have included such agreements in their union shop contracts. See, e.g., Agreement Between Certain Eastern Railroads and Seventeenth Co-operating Labor Organizations $\$ 5$ (Aug. 29, 196\%) cited in Summers, Individual Rights in Collective Agreements and Arbitration, 37 N.Y.U.L. RE: 362,403 n.167. Such procedures are definitely valuable in achicving an clicient sctucment to most dues disputes. However, they do not deprive the emplojec of his statutory right to court protection for his Section 2 Fourth rights. Indeed, lie cxistence of the court remedy is probably necessary to promote the making and impartial enforcement of such agreements.

[36.] For example, suppose the union announces that all members of the union must picket at a particular place and time. One employee refuses to do so. The union revokes his membership and refuses his tendered dues because of this infraction and cites him to the employer for failure to pay dues. The employee is discharged. Clearly the discharge was wrongful, but the employee could obtain no relief by appealing to the union, since the union is justified in revoking his membership for his failure to picket. 
mine how much was actually owed. Ordinarily this is a straightforward task; but sometimes dues provisions are intricate and obscure. In Brady, for instance, the court found it necessary to devote considerable space in the opinion merely to set out Brady's dues obligation under the union security agreement. ${ }^{37}$ This complexity gives the union a convenient way of liquidating uncooperative members and circumventing the statutory ban on the closed shop.

Difficult dues clauses, however, should pose few problems for the courts; certainly none that would require them to defer to the partisan "expertise" of the adjustment boards. For an ambiguous dues clause should be construed strictly against the union and the employer. From the employee's point of view the dues clause is a contract of adhesion; and the least he can expect is bold-face notice of conditions which may cost him his job. In construing the clause, the intent of the parties is irrelevant; the pertinent inquiry is whether the employee has been given fair notice of his obligations. If this strict reading gives the dues clause a different meaning than the parties would have liked, they can easily reopen the agreement and clarify their intentions. All they will have lost is the ability to fire a member who performed what he reasonably believed were his obligations.

When the NLRB decides dues disputes arising under Section 8(a)(3) the intent of the employer in dismissing the employee is conclusively presumed from the facts proved to establish dues payment. ${ }^{38}$ In essence, this creates strict liability on the part of the employer for dismissals not made in accordance with the union security agreement. Similarly, the Section 2 Fourth duty of non-coercion should entail strict liability, so that proof consists only of the agreement and the facts of the employee's conduct. When the employee's livelihood is at stake, liability for an error by the union and an employer should be borne by them, not him.

Dues disputes often arise where the defaulting employee has had reasonable notice of his obligation before dismissal, but can complain that other employees equally delinquent have not been subjected to discharge. ${ }^{39}$ This situation can also be handled satisfactorily under the

[37.] 223 F. Supp. 361, 367-69 (D. Del. 1963).

[38.] [S]pecific proof of intent is unnecessary where employer conduct inherently encourages or discourages union membership.... Thus an employer's protestation that he did not intend to encourage or discourage must be unavailing where $a$ natural consequence of his action was such encouragement or discouragement. Con. cluding that encouragement or discouragement will result, it is presumed that lic
intended such consequence.

Radio Officers' Union v. NLRB, 347 U.S. 17, 45 (1954).

[39.] E.g., Cunningham v. Erie R.R., 266 F.2d 411, 412 (2d Cir. 1959). 
statute. Section 2 Eleventh allows discharge of a defaulting employee only if union membership has been offered to him on "the same terms and conditions as are generally applicable to any other member" and if he has failed "to tender the periodic dues, initiation fees and assessments ... uniformly required as a condition of acquiring or retaining membership." 40 This language seems to prohibit the discharge of one of many delinquent members since membership is not being offered to him on the "same terms and conditions as are generally applicable" and the dues he did not pay were not "uniformly required."41

The courts might reject this interpretation of Section 2 Eleventh, however, reasoning instead that the first words of the proviso, "that no such agreement shall require," 42 indicate that it is only on its face that the agreement must offer membership on substantially equal terms and require uniform dues. On this reading, any delinquent employee may be discharged, regardless of other members' status. But the employee would still be entitled to relief if he could show that the union was guilty of hostile discrimination in singling him out for dismissal. Consequently the union's intent would be at issue, since it could have legitimate motives for its action. ${ }^{43}$

Even under this strict rule, the union member should be able to establish a prima facie case simply by showing that other employees, equally in arrears, were not discharged. The burden would then shift to the union to justify its conduct. The employee would therefore not have to offer direct proof of the union's intent, normally a matter peculiarly within the knowledge of his adversary.

Even if judicial doctrine improves, the discharged employee may be discouraged by the cost of litigation. Under NLRB practice he would

[40.] See note 1 supra.

[41.] A possible difficulty with the strict application could arise in the following situation:

Two employees are equally delinquent in their union dues. One emplojee who until recently had been laid off and has eleven children and a sick wife, had asked the union if he could be permitted to defer payment until happier times, and the union had acquiesced. The other employee has decided that he hates unions and simply refuses to pay his dues. Would Section 2 Fourth-Section 2 Eleventh prevent the latier's dismissal if the former is retained? The answer is no, since union membership must be offered only on the "same terms and conditions as are generally applicable" and this vould seem to allow the union sufficient flexibility to be generous without endangering its ability to fire recalcitrant employees. It is only when the union is discriminating among employees with similar equities that Section 2 Fourth-Section 2 Eleventh would prohibit dismissal.

[42.] See note 1 supra.

[43.] The example in note 41 supra, is a situation where the union's intent in liring the second employee was not "hostile discrimination." It was simply to maintain union discipline. 
receive free help from the general counsel, ${ }^{44}$ but the RLA does not provide him with assigned counsel for necessary litigation. Thus few employees can afford to contest a wrongful dismissal procured by their own union. To redress the balance, counsel fees should be awarded in Section 2 Fourth cases where the union has contested the claim in bad faith. Since the union has fiduciary obligations to its members, for it to oppose what it knows to be a valid dues claim would be to violate its duty of fair representation. A union which has written a clear agreement and adhered to it should have little difficulty establishing good faith.

Another difficulty peculiar to the RLA is ensuring joinder of the union in dues disputes. Section 2 Fourth speaks only of the employer's duty not to coerce the employee, and there is no provision in the RLA comparable to $8(b)(2)$ of the NLRA ${ }^{45}$ which makes it illegal for the union to cause the employer to violate the anticoercion provision. ${ }^{40}$ Thus a literal reading of the RLA seems to give the employee no right of action against the union. Yet the union will generally be the party that has used the dues provision illegally. Typically, the employer has little information and no interest in the situation.

It seems likely, however, that Congress either forgot or considered unnecessary legislation comparable to $8(b)(2)$, since the Senate Report makes it clear that Section 2 Eleventh and Section 2 Fourth were intended to operate exactly like the parallel provisions of the NLRA.47 Nonetheless, the courts have the inherent power to join the union as

[44.] Labor Management Relations Act § 3(d), as amended, 61 Stat. 139 (1947), 29 U.S.C. \& 153(d) (1964).

[45.] $\& 8(\mathrm{~b})(2)$ of the Labor Management Relations Act provides in pertinent part:

(b) It shall be an unfair labor practice for a labor organization or its agents-

(2) to cause or attempt to cause an employer to discriminate against an employec in violation of subsection (a)(3) or to discriminate against an employee with respect to whom membership in such organization has been denied or terminated on some ground other than his failure to tender the periodic dues and the initiation fees uniformly required as a condition of acquiring or retaining membership. . . .

61 Stat. 141 (1947), 29 U.S.C. § 158(b)(2) (1964).

[46.] E.g., Int'l Union of Electrical, Radio \& Machine Workers v. NLRB, 307 F.2d 679 (D.C. Cir. 1962); NLRB v. Aluminum Workers, 230 F.2d 515 (7th Cir. 1956); NLRB v. Biscuit \& Cracker Workers, 222 F.2d 573 (2d Cir. 1955). See Note, The Ability of a Union to Cause a Discharge for Nonpayment of Dues under the Taft-Harlley Act, 45 Gro. L.J. 250 (1957).

[47.] See note 28 supra. The Brady court relied on the following explanation:

It was within Congress' contemplation that both the Union and the carricr would be signatory to the collective bargaining agreements. Since both parties were treated equally in Section 2 (Eleventh), and since Congress knew that the section was an exception to certain prohibitions, it is sound to conciude that Congress thought the Union might also be liable under Section 2 (Fourth) when it caused an illcgal discharge.

Brady v. Trans World Airlines, 223 F. Supp. 361, 370 (D. Del. 1963). 
co-defendant. Under the wholly judicial doctrine of hostile discrimination, the employee has been given an action against the innocent employer as well as the union. ${ }^{48} A$ fortiori, the courts should be able to join the culpable union in Section 2 Fourth cases.

Of course, even if the courts do not make the union a party, the employer can protect himself by including an indemnification clause in the collective bargaining agreement. This was, in fact, exactly the situation in Brady, and the union was only too happy to come into the suit to protect itself. 49

A final problem is speed. The wrongfully dismissed employee should not have to suffer the law's delay before recovering his job. ${ }^{.0}$ Because his claim can be established simply, the courts can fashion a summary procedure to provide temporary relief. Where the employee's ex parte motion and affidavits show an RLA violation, the employee should be restored to his job pending a preliminary hearing. The employer will not be greatly inconvenienced, nor union discipline jeopardized, and the necessity for the trial itself may never arise.

[48.] If the District Court has jursidiction to proceed against the union it is clear, we think, that it has also power to adjudicate the claim against the railroad. It would be absurd to require this closely integrated dispute to be cut up into segments. Cunningham v. Erie R.R., 266 F.2d 411,416 (2d Cir. 1959).

[49.] Brady v. Trans World Airlines, 167 F. Supp. 469, 474 (D. Del. 1958). Indemnification agreements have evidently become commonplace in union sceurity agreements made pursuant to Section 2 Eleventh. Cunningham v. Eric R.R., 358 F.2d G10, 645 (2d Cir. 1966).

[50.] In the Brady litigation, the employec was fired in May, 1956, and the court order restoring him to his job was handed down in September, 1965. Brady v. Trans World Airlines, 223 F. Supp. 361 (D. Del. 1963); 244 F. Supp. 820 (D. Del. 1965). In Cunningham the employee was fired from his job in January, 1955, and the discharge was not determined to be wrongful until July, 1965. Reinstatement actually proved impossible because the employee's job had been eliminated several years after the discharge. Cunningham v. Erie R.R., 243 F. Supp. 571 , 572 (S.D.N.X. 1965). Even when job climination is not involved, such long periods before reinstatement exacerbate the diffaculties of the courts in fashioning proper remedies. It becomes difficult to determine to what position the employee should be restored, since advancement must be considered. The computation of back pay also becomes exceedingly complex since probable raises, in. creases in benefits, and mitigation must all be taken into consideration. 